\title{
https://doi.org/10.46813/2021-134-035 \\ TRIGGERING PULSE GENERATORS DEVELOPED \\ FOR THE HIGH-VOLTAGE DISCHARGERS OF MAGNETIC SYSTEMS AND FOR THE GENERATOR OF PULSE VOLTAGES USED BY THE RELATIVISTIC ELECTRON BEAM ACCELERATOR "TEMP-B"
}

\author{
A.B. Batrakov, A.A. Zinchenko, Yu.F. Lonin, A.G. Ponomarev, S.I. Fedotov \\ National Science Center "Kharkov Institute of Physics and Technology", Kharkiv, Ukraine \\ E-mail: a.batrakov67@gmail.com
}

The pulse generators were developed to trigger the high-voltage dischargers of magnetic systems and the dischargers of the generators of pulsed voltages used by the relativistic electron beam (REB) accelerator "TEMP-B". The description of the triggering pulse generators designed by the NSC KIPT to actuate the dischargers of the pulsed voltage generators (PVG) and the dischargers of magnetic systems has been given. These are used by the commutation systems of capacitor banks with the stored energy margin in the range of 60 to $150 \mathrm{~kJ}$. The generators provide the generation of voltage pulses with the amplitude of up to $20 \mathrm{kV}$.

PACS: 29.20.-c; 29.90. $+\mathrm{r}$

\section{INTRODUCTION}

The REB accelerator "TEMP-B" with the energy reserve of up to $150 \mathrm{~kJ}$ is intended for the generation of the high-power REB pulses and the slowing-down $\mathrm{X}$-ray emission. The generator enables the generation of the REB with the current of 2 to $20 \mathrm{kA}$ and the particle energy of 300 to $800 \mathrm{keV}$. Just one current pulse of the accelerator is able to yield a maximum dose of the slowing-down X-ray emission, i.e. 9100 P. The main power supply source of such an accelerator is the pulse voltage generator (PVG) that was assembled according to the specially updated Arkadev-Marx circuit. It consists of the four (4) parallel operating channels. The shaped high-voltage pulse is sent via the electrode from PVG to the magnet-isolated vacuum diode of the REB accelerator. The diode is divided into two parts. The first part connects the PVG electrode with the insulating column and the second part is a vacuum in the insulating column. The magnetic field is applied to shape and transport the REB and avoid the beam current losses in the vacuum diode. The magnetic field is created by the current flowing through the conical and cylindrical solenoids. The conical solenoid is situated outside the vacuum diode and it provides the magnetic insulation. The cylindrical solenoid is arranged inside the vacuum diode and it is intended for the REB shaping and transporting. To provide a stable operation of the shaping and accelerating line the REB accelerator requires the noiseimmune discharger triggering systems. The transistortype generator circuits developed by us shape the highvoltage pulses of $20 \mathrm{kV}$ that are used to trigger highpower dischargers. These have galvanic decouplers between the input control pulse and the pulses of the devices designed to directly actuate high-power dischargers. These dischargers provide a considerable decrease in electric noises that arise during the operation of the devices of this type and considerably improve a stable operation of the accelerator on the whole.

\section{TRIGGERING PULSE GENERATOR FOR THE HIGH-VOLTAGE DISCHARGERS OF THE PVG}

A successful operation of the REB accelerator "TEMP-B" requires a reliable operation of its numerous units. It can be attained through the stable triggering of the all systems of it [1]. Pulse signals are sent from the synchronizing device to the pulse generator to actuate the high-voltage dischargers of the PVG. Transistortype high-voltage pulse shaper-based circuit was developed to provide a stable operation of triggering dischargers. The generator provides the generation of voltage pulses with the amplitude of up to $20 \mathrm{kV}$ and the current of $5 \mathrm{~A}$ in the short-circuit mode; the pulse duration of the first half-wave is $12 \mu \mathrm{s}$ and the pulse repetition rate is within $10 \mathrm{~Hz}$. Fig. 1 gives the generator circuit designed for the actuation of the high-voltage dischargers of the PVG.

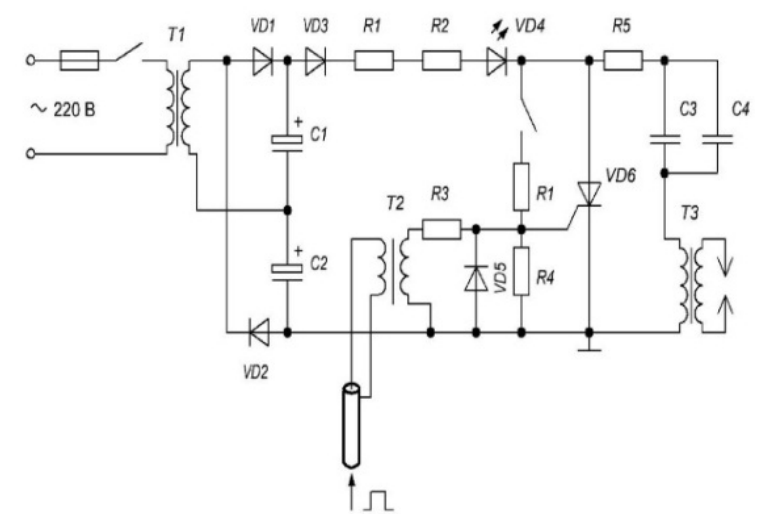

Fig. 1. The generator circuit designed for the actuation of the high-voltage dischargers of the $P V G$

The circuit consists of the dividing transformer T1; the voltage doubler consisting of VD1, VD2, C1 and $\mathrm{C} 2$, storage capacitors $\mathrm{C} 3$ and $\mathrm{C} 4$ and the symistorbased switch-board VD6, and the step-up pulse transformer T3 whose secondary winding sends the signal to the control electrode of the discharger. The symistor VTA41-800V acts as a switch-board that provides the discharge of storage capacitors onto the high-voltage 
transformer. The transformation ratio of the transformer $\mathrm{T} 3$ is equal to 35 . The secondary high-voltage winding of the transformer consists of the four (4) sections and it enables the generation of the triggering pulse within the order of $20 \mathrm{kV}$. The triggering pulse generator developed for the actuation of the dischargers enables the generation of the actuating pulse several times higher than that of similar devices [2]. Fig. 2 gives the voltage pulse oscillogram.

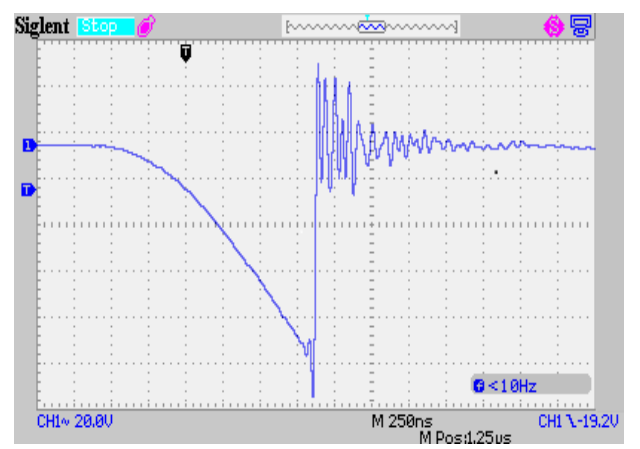

Fig. 2. Output voltage pulse oscillogram in the idling mode

A maximum value of the current that flows in the discharge circuit is defined by the inductance of the primary winding of the transformer and it is equal to about 40 A. Fig. 3 gives the current oscillogram obtained in the short-circuit mode.

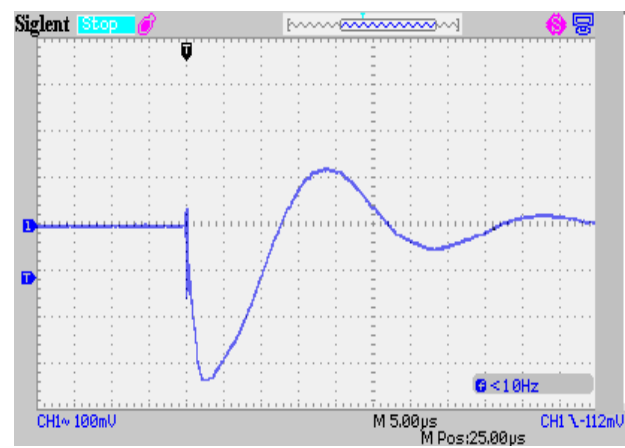

Fig. 3. Triggering current pulse in the short-circuit mode for the active loading of $0.13 \Omega$

The VD6 symistor control pulse is sent from the triggering device via the dividing transformer $\mathrm{T} 2$ and the current limiting resistor R3. The control pulse that actuates the symistor VD6 has a positive polarity with the amplitude of $15 \mathrm{~V}$ and the duration of $4 \mu \mathrm{s}$. The resisters R1 and R2 are intended for the limitation of the charging current of storage capacitors $\mathrm{C} 3$ and $\mathrm{C} 4$. The resistor R5 confines the discharge current of the capacitors $\mathrm{C} 3$ and $\mathrm{C} 4$ to the level of $400 \mathrm{~A}$. The light emitting diode VD4 indicates the operation of the actuating generator. The represented triggering pulse generator circuit allowed us to attain the stable actuation of high voltage dischargers and it can be applied for the power supply systems used by the VPGs and pulse current generators (PCGs) that contribute to the solution of different technological problems relating to the change in the properties of condensed media, modification of the surfaces of polycomposite materials, etc.

\section{TRIGGERING PULSE GENERATORS FOR THE HIGH-VOLTAGE DISCHARGERS OF MAGNETIC SYSTEMS}

Triggering pulse generators used for the actuation of the high-voltage dischargers of magnetic systems generate the pulses that drive the dischargers of conical and cylindrical solenoids [3]. These allow us to create the appropriate conditions for the magnetic insulation and for the beam transportation. The delay in the actuation of the discharger of the cylindrical solenoid is within the order of $15 \mathrm{~ms}$. The magnetic field intensity of the conical solenoid was equal to $4 \mathrm{kE}$ and the intensity of the magnetic field of the cylindrical solenoid intended for the REB focusing and transportation was equal to $11.7 \mathrm{kE}$. Magnetic systems are actuated by the spark dischargers R1 P. 21654, assembly 7 that were developed by the Institute for the Physics Technology of the Academy of Sciences of the Ukrainian Soviet Socialist Republic and these are used as the switch-boards for the energy - intensive capacitor banks. Usually the hydrogen thyratron-based triggering pulse generator circuit is used. The hydrogen thyratron discharges the preliminary charged high-voltage capacitor bank onto the primary winding of the high-voltage transformer. The generated high-voltage pulse is sent from the secondary transformer winding to the control electrode of the discharger. The application of the hydrogen thyratron presupposes the use of the high-power filament transformer, the high-voltage power supply source to charge the storage capacitor, and the shaper of the high voltage driving pulse that is sent to the net-shaped electrode of the thyratron. It takes approximately $5 \ldots 7 \mathrm{~min}$ for the hydrogen thyratron to get prepared for the operation.

The suggested generator circuit allows us to get rid of the large-size transformers, to use standard semiconductor devices and to cut uptime. The triggering pulse generator circuit designed for the actuation of the highvoltage dischargers of magnetic systems is given in Fig. 4.

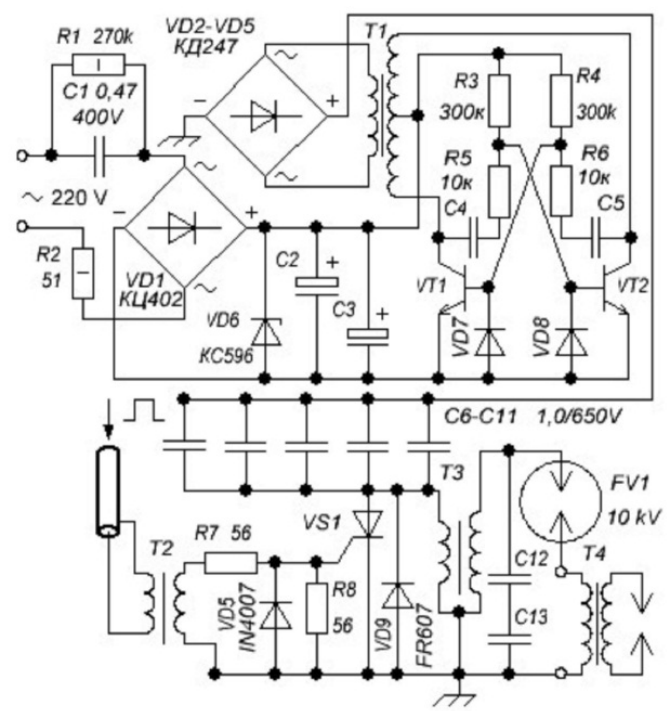

Fig. 4. The triggering pulse generator circuit designed for the actuation of high-voltage dischargers of magnetic systems 
The triggering pulse generator circuit designed for the actuation of the high-voltage dischargers of magnetic systems includes the voltage converter fabricated using the push-pull circuit with the midpoint on the VT1-VT2 transistors. The converter operation frequency is $16 \mathrm{kHz}$. The limitation of the charging current of the capacitors C6 to C11 loccurs at the level of $30 \mathrm{~mA}$ at the initial time instant, using the capacitor $\mathrm{C} 1$ for the input ac voltage circuit. As the capacitors C6 to $\mathrm{C} 11$ are charged the charging current is cut down and the converter is switched to the voltage stabilization mode, maintaining the $\mathrm{C} 6$ to $\mathrm{C} 11$ voltage at the level of $350 \mathrm{~V}$. The standard thyristor VS1-BT12-600 is used for the switching of the capacitors C6-C11. The ignition coil B115-U-XL with the transformation ratio of 88 is used as the step-up transformer. When the thyrister VS1 is switched on via the ignition coil the so-called "resonance charge of the capacitors" C12, C13 occurs [4]. The charging of the capacitors $\mathrm{C} 12$ and $\mathrm{C} 13$ occurs prior to the breakdown of the additional uncontrolled spark discharger FV1. The breakdown voltage of this discharger is within $10 \mathrm{kV}$. The voltage value to which the capacitors $\mathrm{C} 12$ and $\mathrm{C} 13$ are charged is derived from the formula:

$$
U_{c}=\frac{2 U_{i n}^{1} \times C_{o}^{1}}{C_{o}^{1}+C_{s}},
$$

where $U_{c}$ is the $\mathrm{C} 12$ and $\mathrm{C} 13$ capacitor voltage, $U_{\text {in }}^{1}$ is the $\mathrm{C} 6$ through $\mathrm{C} 11$ capacitor voltage driven to the secondary winding of the step-up transformer and it is equal to $U_{\text {in }}^{1}=K_{t r} \cdot U_{\text {in }}=88 \cdot 350 \mathrm{~V}=30.8 \cdot 10^{3} \mathrm{~V}, C_{o}^{1}$, is the C6 - C11 capacitors capacitance driven to the secondary winding of the step-up transformer and it is equal to $C_{o}^{1}=C / K_{t r}^{2}=5 \cdot 10^{-6} \mathrm{~F} / 88^{2}=6.46 \cdot 10^{-10} \mathrm{~F} C_{s}$, is the $\mathrm{C} 12$ and $\mathrm{C} 13$ capacitors capacitance.

The calculated capacitor voltage value is equal to $17.3 \cdot 10^{3} \mathrm{~V}$ and it results in the confident actuation of the uncontrolled spark discharger.

The formula (1) shows that a decrease in the capacitance value of $C_{s}$ results in its increased voltage value and the action time of the high voltage is reduced. Therefore, the capacitance value of $C_{s}$ is selected expecting that the action time of the high voltage that exceeds the value of the breakdown voltage of the spark discharger would be longer than the delay time of the breakdown of this spark discharger.

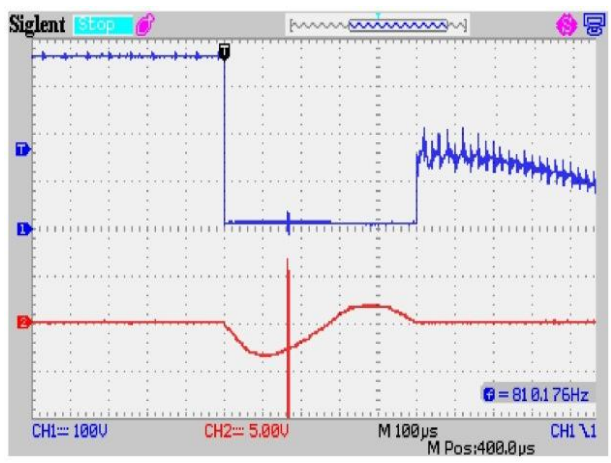

Fig. 5. T3 spark coil voltage and current oscillogram

The discharge of the additional capacitor $\mathrm{C}_{\mathrm{s}}$ via the uncontrolled spark discharger onto the built-in highvoltage transformer of the spark discharger
(R1 P. 21654 assembly 7) results in the actuation of this discharger. The oscillogram in Fig. 5 shows the operation of the triggering circuit.

The oscillogram shows that the T3 coil voltage for beam 1 is $350 \mathrm{~V}$. The current measured on the resistance of $0.3 \Omega$ for beam 2 is $12 \mathrm{~A}$. The current change rate in the spark coil T3 is $0.2 \mathrm{~A} / \mu \mathrm{s}$ that enables the use of the standard tyristor. Fig. 6 gives the oscillogram for the uncontrolled discharger voltage measured using the capacitive voltage divider with the dividing ratio of 200 .

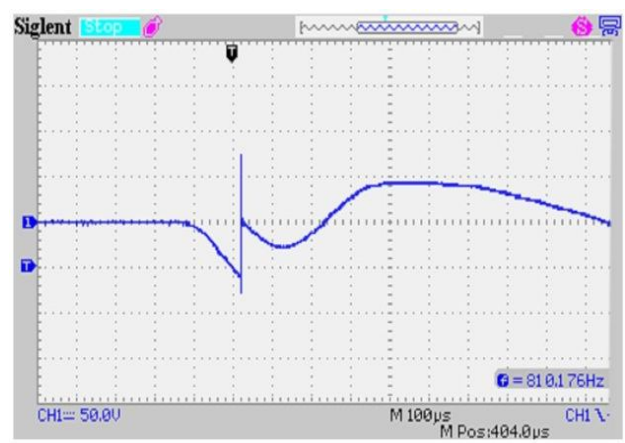

Fig. 6. FV1 uncontrolled discharger voltage oscillogram

The given oscillogram shows that the discharger breakdown occurs at the voltage value of $10 \mathrm{kV}$.

The pulse generators developed for the actuation of high-voltage dischargers allow us to synchronize the operation of the REB accelerator "TEMP-B". Fig. 7 shows the oscillogram for the total magnetic field intensity distribution along the acceleration column axis with an actuation of the two solenoids and the VPG triggering pulse is sent at the maximum intensity in magnetic systems.

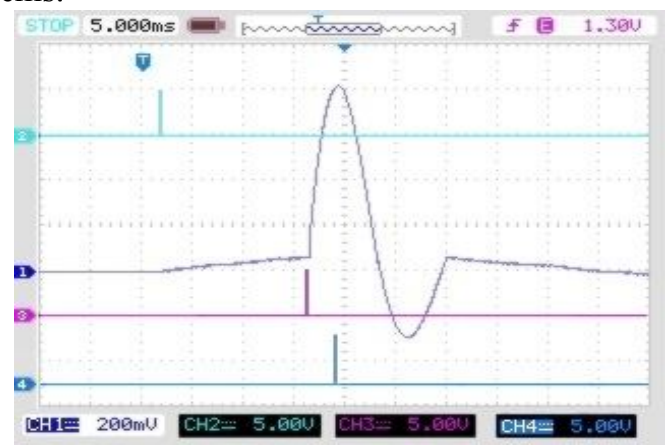

Fig. 7. Oscillogram for control pulses and the total magnetic field intensity distribution along the acceleration column axis

In Fig. 7, beam 1 is the total magnetic field intensity distribution along the acceleration column axis, beam 2 is the first solenoid triggering pulse, beam 3 is the second solenoid triggering pulse, beam 4 is the VPG triggering pulse.

The synchronizing device control pulses provide series actuation of the high-voltage dischargers of magnetic systems and the high-voltage dischargers of the generator of pulse voltages are actuated at the time of a maximum intensity of the magnetic field.

\section{CONCLUSIONS}

The pulse generators developed for the actuation of the high-voltage dischargers of magnetic systems and high-voltage dischargers of the generators of pulse voltages enable the generation of an appropriate triggering 
pulse required for the stable operation of actuating dischargers.

The circuit suggested for the generator of triggering pulses enables the creation of a simple device for triggering pulses with a low-voltage storage capacitor and it permits the use of standard semiconductor devices and allows us to shorten the uptime.

\section{REFERENCES}

1. A.B. Batrakov, E.G. Glushko, A.A. Zinchenko, Y.F. Lonin, A.G. Ponomarev, S.I. Fedotov. Impulse magnetic system of relativistic elektron beam accelerator "TEMP-B" // Problems of Atomic Science and Technology. Series "Plasma Electronics and New Methods of Acceleration”. 2013, № 4, p. 7-9.
2. E.G. Crasthel. Helicing Rainsery Introduction Generator with low-voltage accumulative capacitor and thyristor commutato-rum // Instruments and equipment of the experiment. 2014, № 6, p. 51-56.

3. A.B. Batrakov, E.G. Glushko, A.A. Zinchenko, Y.F. Lonin, A.G. Ponomarev, S.I. Fedotov. Digital triggering device and generator of starting pulses for ignition of spark gaps of reb accelerator "TEMP" // East European Journal of Physics. 2019, № 4, p. 7782.

4. G.A. Month. Pulse energy and electronics. M.: "Science", 2004, p. 704.

Article received 16.06.2021

\section{ГЕНЕРАТОРЫ ИМПУЛЬСОВ ЗАПУСКА ВЫСОКОВОЛЬТНЫХ РАЗРЯДНИКОВ ДЛЯ МАГНИТНЫХ СИСТЕМ И ГЕНЕРАТОРА ИМПУЛЬСНЫХ НАПРЯЖЕНИЙ УСКОРИТЕЛЯ РЕЛЯТИВИСТСКИХ ЭЛЕКТРОННЫХ ПУЧКОВ «ТЕМП-Б»}

А.Б. Батраков, А.А. Зинченко, Ю.Ф. Лонин, А.Г. Пономарев, С.И. Федотов

Разработаны генераторы импульсов для запуска высоковольтных разрядников магнитных систем и генератора импульсных напряжений ускорителя релятивистских электронных пучков (РЭП) «ТЕМП-Б». Приведено описание генераторов и рассмотрена их работа с разрядниками, спроектированными в ННЦ ХФТИ, которые используются в системах коммутации конденсаторных батарей с энергетическим запасом от 60 до 150 кДж. Генераторы обеспечивают получение импульсов напряжения с амплитудой до 20 кВ.

\section{ГЕНЕРАТОРИ ІМПУЛЬСІВ ЗАПУСКУ ВИСОКОВОЛЬТНИХ РОЗРЯДНИКІВ ДЛЯ МАГНІТНИХ СИСТЕМ І ГЕНЕРАТОРА ІМПУЛЬСНИХ НАПРУГ ПРИСКОРЮВАЧА РЕЛЯТИВІСТСЫКИХ ЕЛЕКТРОННИХ ПУЧКІВ «ТЕМП-Б»}

\section{О.Б. Батраков, А.А. Зінченко, Ю.Ф. Лонін, А.Г. Пономарьов, С.І. Федотов}

Розроблено генератори імпульсів для запуску високовольтних розрядників магнітних систем і генератора імпульсних напруг прискорювача релятивістських електронних пучків (РЕП) «ТЕМП-Б». Приведено опис генераторів і розглянута їх робота з розрядниками, спроектованими в ННЦ ХФТІ, які використовуються в системах комутації конденсаторних батарей з енергетичним запасом від 60 до 150 кДж. Генератори забезпечують отримання імпульсів напруги з амплітудою до 20 кВ. 